\title{
Biocontrol of Cucumber Diseases in the Field by Plant Growth-Promoting Rhizobacteria With and Without Methyl Bromide Fumigation
}

\author{
G. S. Raupach, Taensa Inc., Agriculture Center Bldg. 6200, Alfred-Nobel Str. 50, 40789 Monheim, Germany; and \\ J. W. Kloepper, Department of Entomology and Plant Pathology, Auburn University, Auburn, AL 36849-5409
}

\begin{abstract}
Raupach, G. S., and Kloepper, J. W. 2000. Biocontrol of cucumber diseases in the field by plant growth-promoting rhizobacteria with and without methyl bromide fumigation. Plant Dis. 84:1073-1075.

Field trials were conducted in 1996 and 1997 to determine the effect of plant growth-promoting rhizobacteria (PGPR) strains, which previously were found to induce systemic resistance in cucumber, on cucumber plant growth and on naturally occurring cucumber diseases with and without methyl bromide fumigation. Seven PGPR seed treatments included single-strain treatments and mixtures of Bacillus pumilus strain INR7, Curtobacterium flaccumfaciens strain ME1, and Bacillus subtilis strain GB03. In both years, in the absence of methyl bromide, all seven PGPR treatments significantly promoted plant growth, compared to the non-treated control, while with methyl bromide fumigation, only 3 and 1 of the same PGPR treatments promoted growth significantly in 1996 and 1997, respectively. In 1996, main runner length of plants in all seven PGPR treatments without fumigation was statistically equivalent to the main runner length of the nontreated control with methyl bromide fumigation. Naturally occurring foliar diseases were angular leaf spot, caused by Pseudomonas syringae pv. lachrymans in 1996, and a mixed infestation of angular leaf spot and anthracnose, caused by Colletotrichum orbiculare in 1997. In both years, all PGPR treatments significantly reduced severity of foliar disease, compared to the nontreated control, with and without methyl bromide. Mixtures of PGPR strains showed a higher level of disease protection in both years with and without methyl bromide. The results indicate that attempts to develop PGPR-mediated induced systemic resistance into components of vegetable integrated pest management should not be negatively impacted by the planned withdraw of $\mathrm{MeBr}$ from standard vegetable production and that PGPR may help compensate for reduced plant growth often seen without methyl bromide fumigation.
\end{abstract}

Additional keywords: Cucumis sativus L., elicitor, systemic acquired resistance

Concerns about impacts of agrichemicals on water quality and food safety have led to enhanced research aimed at developing alternative approaches for managing crop diseases (17). Among the many possible alternatives are elicitors of host resistance, which are treatments that lead to induced systemic resistance (ISR), also referred to as systemic acquired resistance, in crop plants (19). There are many reports in the literature that demonstrate ISR in laboratory or greenhouse experiments, including the use of abiotic and biotic elicitors (18). While most of these inducing agents have not been tested under field conditions and some have been shown to have negative side effects such as phytotoxicity (19), a few reports demonstrate that the general phenomenon of ISR may also occur in the field $(4,8,13,26,28)$. Widespread implementation of ISR has not

Corresponding author: Joseph W. Kloepper e-mail: jkloeppe@acesag.auburn.edu

Accepted for publication 22 May 2000.

Publication no. D-2000-0728-02R

(c) 2000 The American Phytopathological Society been accomplished, partly because classical ISR relies on induction via initial infection of necrotizing pathogens, which is not a viable agronomic practice (1). The recent introduction of a synthetic elicitor (Benzo(1,2,3) thiadiazole-7-carbothioic acid S-methyl ester), Actigard (Novartis Crop Protection, Inc., Basel, Switzerland), currently available in Germany as Bion, demonstrates the progress toward practical agricultural use of the technology of ISR.

Development of sustainable production practices for high-value fruit and vegetable crops requires replacements for methyl bromide $(\mathrm{MeBr})$, which is currently used as a preplant biocidal soil fumigant and is part of recommended vegetable production practices in the southeastern United States. Since the 1970s, MeBr has been used almost exclusively, because of its consistent and effective control of soilborne pests under a range of soil moisture and temperature regimes, relatively low cost, and ease of handling (2). In 1995, MeBr was one of the five most commonly used pesticides in the United States with annual applications between 25,000 and 27,000 MT (27). Concerns about the contribution of $\mathrm{MeBr}$ to the stratospheric depletion of ozone have led to an impending worldwide ban on its production and use in agriculture $(6,20)$. Several broad-spectrum fumigants have been suggested as alternatives to $\mathrm{MeBr}$ (27), including metam-sodium, dichloropropene, chloropicrin, and dazomet (7). It has been suggested that methyl iodide might be the new alternative "magic bullet" fumigant that is as efficacious and widely applicable as $\mathrm{MeBr}$ (21), but a single tactic to control soilborne pests still leaves producers vulnerable to future regulatory and marketing policies (5). Soil solarization $(11,12)$ is proposed as another alternative to preplant fumigation with $\mathrm{MeBr}$, since it has been shown to be costeffective, compatible with other pest management tactics, and readily integrated into standard production systems (5). It is generally agreed that the removal of $\mathrm{MeBr}$ will require the use of a diversity of management practices, with less dependence on single-chemical strategies and greater use of biological and ecologically based pest management strategies (3).

Research over the past years has demonstrated that ISR can be a potential mechanism by which plant growth-promoting rhizobacteria (PGPR) demonstrate biological disease control (14). In cucumber, seed treatment with PGPR has resulted in ISR against several pathogens in greenhouse and field experiments $(15,16,23,25,28)$. Field studies, however, have been conducted under standard cultural practices for vegetable production, which include fumigation with $\mathrm{MeBr}$. Given the phase-out of $\mathrm{MeBr}$, it is important to determine if PGPR-mediated ISR is effective without MeBr. Accordingly, the goal of this study was to determine if PGPR strains with known ISR activity, repeatedly seen in $\mathrm{MeBr}$-fumigated field trials, also reduce diseases of cucumber (Cucumis sativus L.) without fumigation. Because mixtures of PGPR strains with ISR activity have recently been reported to improve efficacy and enhance biological control consistency $(23,24)$, they were also evaluated in this study with and without $\mathrm{MeBr}$.

\section{MATERIALS AND METHODS}

Bacterial cultures. Three PGPR strains were used that previously demonstrated ISR activity in cucumber against various pathogens $(14,22,23,25)$-Bacillus pumilus strain INR7, Curtobacterium flaccumfaciens strain ME1, and Bacillus subtilis strain GB03. For long-term storage, cultures were maintained at $-80^{\circ} \mathrm{C}$ in tryptic soy 
broth (TSB, Difco Laboratories, Detroit, MI) amended with $20 \%$ glycerol. PGPR were applied to seeds by scraping 24-h colonies off individual tryptic soy agar (TSA) plates into $20 \mathrm{ml}$ of $0.02 \mathrm{M}$ potassium phosphate buffer, $\mathrm{pH} 7.0$, mixing an equal volume of this suspension with $2 \%$ methylcellulose, and then mixing this with cucumber seeds and air-drying overnight in a laminar flow hood. For treatments consisting of strain mixtures, equal volumes of individual strain suspensions were com- bined prior to mixing with methylcellulose. Mean populations achieved by these treatments were $10^{8}$ to $10^{9} \mathrm{CFU} /$ seed for single-strain treatments and $10^{9}$ to $10^{10}$ $\mathrm{CFU} /$ seed for strain mixtures.

Field trials (1996). In 1996, two field trials were conducted at the E.V. Smith Horticulture Substation in Shorter, AL, one trial with and one without $\mathrm{MeBr}$. The trials were in adjacent fields on the substation. The non-fumigated field had received no $\mathrm{MeBr}$ for at least the 3 previous years. In

Table 1. .Promotion of plant growth and protection against angular leaf spot disease by plant growthpromoting rhizobacteria (PGPR) strains and mixtures with and without methyl bromide fumigation, 1996 field trials on cucumber

\begin{tabular}{lccccc}
\hline & \multicolumn{2}{c}{ Mean main runner length $(\mathbf{c m})^{\mathbf{w}}$} & & \multicolumn{2}{c}{ Angular leaf spot (disease index) } \\
\cline { 2 - 3 } \cline { 5 - 6 } Treatment & $\mathbf{M e B r}$ & No fumigation & & MeBr & No fumigation \\
\hline Control & $59.9 \mathrm{c}^{\mathrm{z}}$ & $50.5 \mathrm{c}$ & & $3.27 \mathrm{a}$ & $3.12 \mathrm{a}$ \\
INR7 & $89.1 \mathrm{a}$ & $83.1 \mathrm{a}$ & & $1.40 \mathrm{c}$ & $1.33 \mathrm{c}$ \\
ME1 & $68.1 \mathrm{bc}$ & $75.9 \mathrm{ab}$ & & $2.08 \mathrm{~b}$ & $1.91 \mathrm{~b}$ \\
GB03 & $65.7 \mathrm{bc}$ & $67.7 \mathrm{~b}$ & & $2.05 \mathrm{~b}$ & $1.92 \mathrm{~b}$ \\
INR7+ME1 & $76.6 \mathrm{ab}$ & $81.0 \mathrm{a}$ & & $1.46 \mathrm{c}$ & $1.51 \mathrm{bc}$ \\
INR7+GB03 & $75.5 \mathrm{ab}$ & $78.9 \mathrm{ab}$ & & $1.35 \mathrm{c}$ & $1.40 \mathrm{c}$ \\
ME1+GB03 & $71.1 \mathrm{bc}$ & $77.8 \mathrm{ab}$ & & $1.98 \mathrm{~b}$ & $1.73 \mathrm{bc}$ \\
INR7+ME1+GB03 & $59.9 \mathrm{c}$ & $85.6 \mathrm{a}$ & & $1.25 \mathrm{c}$ & $1.50 \mathrm{c}$ \\
& & & & & \\
LSD $(P=0.05)$ & 15.5 & 11.4 & & 0.38 & 0.41 \\
\hline
\end{tabular}

${ }^{v}$ Two experiments were conducted, one trial with methyl bromide fumigation (67\% methyl bromide $+33 \%$ chloropicrin at $393 \mathrm{~kg} / \mathrm{ha}$ was injected into raised beds followed immediately by application of black plastic mulch) and one trial without fumigation.

${ }^{\text {w }}$ Mean main runner length in $\mathrm{cm}$ was measured 31 days after planting.

${ }^{x}$ Disease assessment was done 57 days after planting according to a disease rating scale from 0 to $5(0=$ no lesions, $1=1$ to $20 \%$ of leaf area with lesions, $2=20$ to $40 \%$ of leaf area with lesions, $3=40$ to $60 \%$ of leaf area with lesions, $4=60$ to $80 \%$ of leaf area with lesions, and $5=80$ to $100 \%$ of leaf area with lesions) based on the degree of angular leaf spot infestation caused by Pseudomonas syringae pv. lachrymans, which was the predominant disease naturally occurring in 1996 in the field.

y PGPR strain identifications: INR7 = Bacillus pumilus, ME1 = Curtobacterium flaccumfaciens, and GB03 = Bacillus subtilis; bacteria were applied as seed coat treatments.

${ }^{\mathrm{z}}$ Means with different letters are significantly different at $P=0.05$ according LSD test procedure using GLM in PC-SAS.

Table 2. Promotion of plant growth and protection against anthracnose and angular leaf spot disease by PGPR strains and mixtures with and without methyl bromide fumigation, 1997 field trials on cucumber $^{\mathrm{V}}$

\begin{tabular}{|c|c|c|c|c|}
\hline \multirow[b]{2}{*}{ Treatment $^{y}$} & \multicolumn{2}{|c|}{$\begin{array}{l}\text { Mean main runner length } \\
(\mathbf{c m})^{\mathrm{w}}\end{array}$} & \multicolumn{2}{|c|}{$\begin{array}{c}\text { Anthracnose } \& \text { angular leaf spot } \\
\left(\text { disease index) }^{\mathrm{x}}\right.\end{array}$} \\
\hline & $\mathrm{MeBr}$ & No fumigation & $\mathrm{MeBr}$ & No fumigation \\
\hline Control & $47.4 b^{z}$ & $31.9 \mathrm{c}$ & $2.83 \mathrm{a}$ & $3.10 \mathrm{a}$ \\
\hline INR7 & $59.7 \mathrm{a}$ & $42.2 \mathrm{~b}$ & $1.91 \mathrm{~cd}$ & $1.85 \mathrm{c}$ \\
\hline ME1 & $55.5 \mathrm{ab}$ & $39.7 \mathrm{~b}$ & $2.25 \mathrm{~b}$ & $2.27 \mathrm{~b}$ \\
\hline GB03 & $58.1 \mathrm{ab}$ & $40.9 \mathrm{~b}$ & $2.01 \mathrm{bc}$ & $2.19 \mathrm{~b}$ \\
\hline INR7+ME1 & $57.7 \mathrm{ab}$ & $39.9 \mathrm{~b}$ & $1.46 \mathrm{e}$ & $1.24 \mathrm{e}$ \\
\hline INR7+GB03 & $55.1 \mathrm{ab}$ & $44.2 \mathrm{ab}$ & $1.68 \mathrm{de}$ & $1.62 \mathrm{~cd}$ \\
\hline ME1+GB03 & $57.4 \mathrm{ab}$ & $43.8 \mathrm{ab}$ & $1.69 \mathrm{de}$ & $1.42 \mathrm{de}$ \\
\hline INR7+ME1+GB03 & $55.7 \mathrm{ab}$ & $48.2 \mathrm{a}$ & $1.40 \mathrm{e}$ & $1.17 \mathrm{e}$ \\
\hline $\operatorname{LSD}(P=0.05)$ & 11.8 & 5.7 & 0.30 & 0.26 \\
\hline
\end{tabular}

${ }^{\mathrm{v}}$ Two experiments were conducted, one trial with methyl bromide fumigation $(67 \%$ methyl bromide $+33 \%$ chloropicrin at $393 \mathrm{~kg} / \mathrm{ha}$ was injected into raised beds followed immediately by application of black plastic mulch) and one trial without fumigation.

${ }^{\text {w}}$ Mean main runner length in centimeters was measured 36 days after planting.

${ }^{\mathrm{x}}$ Disease assessment was done 57 days after planting according to a disease rating scale from 0 to 5 $(0=$ no lesions, $1=1$ to $20 \%$ of leaf area with lesions, $2=20$ to $40 \%$ of leaf area with lesions, $3=$ 40 to $60 \%$ of leaf area with lesions, $4=60$ to $80 \%$ of leaf area with lesions, and $5=80$ to $100 \%$ of leaf area with lesions) based on the degree of disease infestation per plant caused by both anthracnose and angular leaf spot, which occurred naturally in the 1997 field season.

${ }^{y}$ PGPR strain identifications: INR7 = Bacillus pumilus, ME1 = Curtobacterium flaccumfaciens, and GB03 = Bacillus subtilis; bacteria were applied as seed coat treatments.

${ }^{\mathrm{z}}$ Means with different letters are significantly different at $P=0.05$ according LSD test procedure using GLM in PC-SAS. the fumigated trial, $67 \% \mathrm{MeBr}+33 \%$ chloropicrin was injected into raised beds at $393 \mathrm{~kg} / \mathrm{ha}$ followed immediately by application of black plastic mulch, and this was done 2 to 3 weeks prior to planting. Plastic mulch was used in all trials in both years. Both trials relied on natural disease infestation, and cucumber cv. Straight 8 was planted in a randomized complete block design. There were eight treatments, each replicated six times, with eight plants per replication. Treatments included seed bacterization with three individual PGPR strains (INR7, ME1, and GB03), all possible strain combinations, and a non-bacterized control. Seeds were hand-planted, and cross contamination was avoided by using disposable latex gloves, which were changed between treatments. Cultural practices were done according to recommendations of the Alabama Agricultural Experiment Station and included fertilization through drip irrigation. Plant growth was monitored 31 days after planting (DAP) as main runner length in centimeters, and foliar disease severity was assessed at 57 DAP using a visual disease rating scale from 0 to 5 , in which $0=$ no lesions, $1=1$ to $20 \%$ of leaf area with lesions, $2=20$ to $40 \%$ of leaf area with lesions, $3=40$ to $60 \%$ of leaf area with lesions, and $5=80$ to $100 \%$ of leaf area with lesions.

Field trials (1997). In 1997, another two field trials were conducted at the same substation, designed as a repeat of the previous year to investigate the efficacy of the same PGPR treatments under natural field infestation, with and without $\mathrm{MeBr}$ fumigation. Main runner length of cucumber plants, as a measurement of plant growth promotion, was recorded at $36 \mathrm{DAP}$ in both trials, and the disease index was determined at 57 DAP based on the same rating scale as described above.

Statistical analyses. Analysis of variance was performed for each experiment using the general linear models (GLM) procedure, and treatment means were separated by the least significant difference (LSD) test at $P=0.05$ with SAS software (SAS Institute, Cary, NC).

\section{RESULTS}

Field trials (1996). Significant plant growth promotion was observed (Table 1) by all seven PGPR treatments compared to the non-bacterized control in the non-fumigated trial, while with $\mathrm{MeBr}$ fumigation, only three of the same seven treatments caused significant growth promotion. Angular leaf spot, caused by $P$. syringae pv. lachrymans, was the predominant naturally occurring disease in 1996. All PGPR treatments significantly reduced disease severity, compared to the non-treated control, under both fumigated and non-fumigated conditions. PGPR mixtures of INR7 and GB03, either in a two-way or threeway combination, showed the highest de- 
gree of disease protection with or without $\mathrm{MeBr}$ fumigation (Table 1).

Field trials (1997). As in 1996, all seven PGPR treatments increased plant growth, compared to the non-bacterized control, in the non-fumigated trial. In contrast, in the $\mathrm{MeBr}$ fumigated trial, only one PGPR treatment significantly enhanced plant growth (Table 2). In 1997, both anthracnose and angular leaf spot occurred and, consequently, plant disease ratings were based on the amount of necrotic lesions from both leaf pathogens. All PGPR treatments reduced disease significantly in comparison to the non-bacterized control both with and without $\mathrm{MeBr}$, and the level of significance was greater with strain-mixtures than with individual PGPR strains. The three-way combination of PGPR strains produced the longest mean main runner length of $48.2 \mathrm{~cm}$ without fumigation, which was comparable with the mean main runner length of 47.4 $\mathrm{cm}$ for the control treatment with $\mathrm{MeBr}$ fumigation.

\section{DISCUSSION}

The results from this two-year field study clearly demonstrate that PGPR-mediated ISR activity, based on protection against naturally occurring foliar pathogens, occurs both with and without $\mathrm{MeBr}$. In addition, plant growth promotion by PGPR without $\mathrm{MeBr}$ fumigation resulted in mean runner lengths statistically equivalent to the fumigated control, occurring in 1996 with all PGPR treatments and in 1997 with the three-strain combination. Hence, PGPR hold promise as alternatives for methyl bromide, since over two years, they resulted in a compensation for the classically reported lower plant growth without $\mathrm{MeBr}$.

PGPR-mediated ISR led to reductions against one or two naturally occurring diseases in both test years, both with and without $\mathrm{MeBr}$ fumigation. In both years, there was a trend to enhanced disease reduction with mixtures of PGPR strains compared to single strains, which agrees with a previous study (24). A possible advantage of mixtures is that different strains may have different mechanisms, and by combining them in mixed inoculants a greater spectrum of activity may be utilized (10). Even if PGPR strain combinations do not always have additive or synergistic effects compared to single strain applications, mixtures may be justified if consistency of PGPR response is improved through the use of mixtures. Combinations of bacteria would be expected to provide improved adaptability to soils, multiple pathogens, and environments (1). If soil conditions vary, in a two-strain mixture chances are higher that at least one strain might be active under a certain set of conditions in order to induce resistance in plants and reduce disease levels.

The impending loss of $\mathrm{MeBr}$ as a preplant soil fumigant has stimulated devel- opment of a number of ecologically based approaches to disease and pest management (27). Fravel (9) demonstrated that the application of the antagonists Talaromyces flavus and Gliocladium roseum in combination with low rates of fumigation with Vapam (metam-sodium) reduced the incidence of Verticillium wilt on eggplant. One main focus in replacing $\mathrm{MeBr}$ will be on the incorporation of biological control agents into solarized, fumigated, or nontreated soils. The results from our studies indicate that PGPR treatments can compensate for $\mathrm{MeBr}$ fumigation as shown by plant growth-promotion and significantly reduce disease expression. With the loss of $\mathrm{MeBr}$, there will be no single replacement that will provide similar efficacy for all pest and disease problems, but alternatives such as PGPR with ISR activity are potential components for IPM practices to replace $\mathrm{MeBr}$.

\section{ACKNOWLEDGMENTS}

This research was supported by USDA NRI grant 9437312-0625.

\section{LITERATURE CITED}

1. Backman, P. A., Wilson, M., and Murphy, J. F. 1997. Bacteria for biological control of plant diseases. Pages 95-109 in: Environmentally Safe Approaches to Crop Disease Control. N. A. Rechcigl and J. E. Rechcigl, eds. CRC Lewis Publishers, Boca Raton, FL.

2. Bewick, T. A. 1989. Use of soil sterilants in Florida vegetable production. Acta Hortic. 255:61-72.

3. Board on Agriculture and National Research Council 1996. Ecologically Based Pest Management-New Solutions for a New Century. National Academy Press, Washington, DC.

4. Caruso, F. L., and $\mathrm{Ku}$, J. 1977. Field protection of cucumber, watermelon, and muskmelon against Colletotrichum lagenarium by Colletotrichum lagenarium. Phytopathology 67:1290-1292.

5. Chellemi, D. O., Olson, S. M., Mitchell, D. J., Secker, I., and McSorley, R. 1997. Adaptation of soil solarization to the integrated management of soilborne pests of tomato under humid conditions. Phytopathology 87:250-258.

6. Clean Air Act. 1990. Title VI-Stratospheric Ozone Protection. Pub. L. 101-549, Sect. 6001-618, 104 Stat. 2649, 6272. As amended. U. S. Congress, Washington, DC.

7. Csinos, A. S., Johnson, W. C., Johnson, A. W., Sumner, D. R., McPherson, R. M., and Gitaitis, R. D. 1997. Alternative fumigants for methyl bromide in tobacco and pepper transplant production. Crop Prot. 16:585-594.

8. Dehne, H. W., Stenzel, K., and Schönbeck, F. 1984. The efficiency of induced resistance under practical culture conditions. III. Reproduction of powdery mildew on induced resistant plants. J. Plant Dis. Prot. 91:258-265.

9. Fravel, D. R. 1996. Interaction of biocontrol fungi with sublethal rates of metham sodium for control of Verticillium dahliae. Crop Prot. 15:115-119.

10. Handelsman, J., and Stabb, E. V. 1996. Biocontrol of soilborne plant pathogens. The Plant Cell 8:1855-1869.

11. Katan, J. 1981. Solar heating (solarization) of soil for control of soilborne pests. Annu. Rev. Phytopathol. 19:211-236.

12. Katan, J. 1993. Replacing pesticides with nonchemical tools for the control of soilborne pathogens-A realistic goal. Phytoparasitica 21:95-99.

13. Kehlenbeck, H., Krone, C., Oerke, E. C., and
Schönbeck, F. 1994. The effectiveness of induced resistance on yield of mildewed barley. J. Plant Dis. Prot. 101:11-21.

14. Kloepper, J. W., Zehnder, G. W., Tuzun, S Murphy, J. F., Wei, G., Yao, C., and Raupach, G. S. 1996. Toward agricultural implementation of PGPR-mediated induced systemic resistance against crop pests. Pages 165-174 in: Advances in Biological Control of Plant Diseases. T. Wenhua, R. J. Cook, and A. Rovira, eds. China Agricultural University Press, Beijing.

15. Liu, L., Kloepper, J. W., and Tuzun, S. 1995. Induction of systemic resistance in cucumber against Fusarium wilt by plant growth-promoting rhizobacteria. Phytopathology 85:695-698.

16. Liu, L., Kloepper, J. W., and Tuzun, S. 1995. Induction of systemic resistance in cucumber against bacterial angular leaf spot by plant growth-promoting rhizobacteria. Phytopathology 85:843-847.

17. Lumsden, R. D., Lewis, J. A., and Fravel, D. R. 1995. Formulation and delivery of biocontrol agents for use against soilborne pathogens. Pages 166-182 in: Biological Pest Control Agents: Formulation and Delivery. F. R. Hall and J. W. Barry, eds. American Chemical Society, Washington, DC.

18. Lyon, G. D., and Newton, A. C. 1997. Do resistance elicitors offer new opportunities in integrated disease control strategies? Plant Pathol. 46:636-641

19. Lyon, G. D., Reglinski, T., and Newton, A. C. 1995. Novel disease control compounds: The potential to 'immunize' plants against infection. Plant Pathol. 44:407-427.

20. Noling, J. W., and Becker, J. O. 1994. The challenge of research and extension to define and implement alternatives to methyl bromide. J. Nematol. (Suppl.) 26: 573-586.

21. Ohr, H. D., Sims, J. J., Grech, N. M., Becker, J. O., and McGiffen, M. E. 1996. Methyl iodide, an ozone-safe alternative to methyl bromide as a soil fumigant. Plant Dis. 80:731-735.

22. Raupach, G. S., and Kloepper, J. W. 1997. Biological control of Rhizoctonia solani (AG4) in Cucumis sativus L. with plant growth promoting rhizobacteria. (Abstr.) Phytopathology 87:S81-82.

23. Raupach, G. S., and Kloepper, J. W. 1997. Integrated pest management of multiple cucumber pathogens through PGPR-mediated induced systemic resistance. Pages 281-282 in: Plant Growth-Promoting RhizobacteriaPresent Status and Future Prospects. Proceedings of the Fourth International Workshop on Plant Growth-Promoting Rhizobacteria. A. Ogoshi, K. Kobayashi, Y. Homma, F. Kodama, N. Kondo, and S. Akino, eds Nakanishi Printing, Sapporo, Japan.

24. Raupach, G. S., and Kloepper, J. W. 1998 Mixtures of plant growth-promoting rhizobacteria (PGPR) enhance biological control of multiple cucumber pathogens. Phytopathology 88:1158-1164.

25. Raupach, G. S., Liu, L., Murphy, J. F., Tuzun, S., and Kloepper, J. W. 1996. Induced systemic resistance in cucumber and tomato against cucumber mosaic cucumovirus using plant growth-promoting rhizobacteria (PGPR). Plant Dis. 80:891-894.

26. Reglinski, T., Newton, A. C., and Lyon, G. D. 1994. Assessment of the ability of yeast-derived resistance elicitors to control barley powdery mildew in the field. J. Plant Dis. Prot. 101:1-10.

27. Ristaino, J. B., and Thomas, W. 1997. Agriculture, methyl bromide, and the ozone hole Can we fill the gaps? Plant Dis. 81:964-977.

28. Wei, G., Kloepper, J. W., and Tuzun, S. 1996 Induced systemic resistance to cucumber diseases and increased plant growth by plant growth-promoting rhizobacteria under field conditions. Phytopathology 86:221-224. 